\title{
UPAYA ISLAMISASI ILMU PENGETAHUAN DAN IMPLIKASINYA TERHADAP PENDIDIKAN ISLAM
}

\author{
Iswati \\ Fakultas Agama Islam \\ Universitas Muhammadiyah Metro \\ Iswatiummetro@yahoo.com
}

\begin{abstract}
The purpose of this paper is to examine how the real efforts of Islamization of science and its implications tehadap Islamic education, and to prove that the idea of Islamization of knowledge is one of the phenomena of contemporary thinking movement activists of the Islamic world in the Era of the 1970s until the early 1980s. Operationally this study apply the methods of data analysis. The use of descriptive data analysis methods intended to analyze the thoughts and ideas of Islamization of science and its implications for the foundations of Islamic education. The primary sources referenced in this research is the work of thought Ismail al-Faruqi related to the concept of Islamization of knowledge with other Muslim thinkers like Syed Muhammad Naquib AlAttas as it is known that since the onslaught of the discourse of Islamization knowledge, it invites experts to discuss. Among Muslim scholars have argued the importance of science to believe that science is necessary for Islamize, considering science in their outlook had been poisoned ideology and values of Western philosophy that much against the teachings of Islam. Al-Faruqi and Al-Attas appeared in their midst as the two central figures that are persistent and critical devote his ideas in modern science Islamization program. In their minds, the reality of the education that develops today embraces two educational systems, namely the system of Islamic education and secular education system, within the framework of the Islamisation of knowledge of both education system should be integrated into a system that is holistic so create education system powerful both materially and spiritually.
\end{abstract}

Keywords: Islamization, Science, Islamic Education

\section{PENDAHULUAN}

Dalam perspektif sejarah, penggunaan nalar dalam rangka pengembangan ilmu dalam Islam disamping tentunya penggunaan porsi wahyu untuk mengimbangi keterbatasan nalar manusia dalam pencarian pengetahuan hakiki, tampaknya menjadi isu yang menarik sejak dari awal kemunculan Islam itu sendiri sebagai sebuah agama yang sangat menghormati pengembangan ilmu, karena kebenaran wahyu adalah absolut, maka argumen akal (nalar) tentang kebenaran wahyu tidak memberikan pengaruh apapun terhadap sejatinya kebenaran itu. Demikian sebaliknya, argumen akal yang menyatakan ketidak benaran wahyu tidak lantas membuat wahyu itu menjadi tidak benar, akan tetapi apabila akal melakukan penalaran yang valid, maka ia akan sesuai dengan kebenaran wahyu. Kesahihan proses transmisi data autoritatif melahirkan ilmu 
tafsir dan ilmu hadits yang kemudian berkembang manjadi landasan ilmu-ilmu lainnya. ${ }^{1}$

Dengan demikian al-Qur'an dan Sunnah adalah rujukan ilmu-ilmu Islam. al-Quran merupakan himpunan wahyu yang menjadi dalil ilmu-ilmu. Dalil disini mengandung arti petunjuk adanya ilmu, bukan ilmu itu sendiri oleh karena itu sejarah menunjukan fakta bahwa al Qur'an mendorong umatnya untk menciptakan ide-ide ilmu pengetahuan yang menjadi dasar perkembangan ilmuilmu dikemudian hari. ${ }^{2}$

Dalam Islam ilmu merupakan salah satu perantara untuk memperkuat keimanan. Iman hanya akan bertambah dan menguat jika disertai ilmu pengetahuan. "science without religion is blind, religion without science is demage ". Kemajuan umat Islam dalam penguasaan ilmu pengetahuan lebih menonjol pada abad pertengahan, ketika umat Islam tidak hanya tampil sebagai sebuah komunitas ritual tapi juga sebagai komunitas intelektual.

Secara historis kemajuan Ilmu Pengetahuan di kalangan umat Islam terlihat ketika mereka memasuki zaman keemasanya dengan maraknya perkembangan ilmu pengetahuan dalam berbagai disiplinnya. Hal yang sedemikian tersebut, walaupun tidak menggunakan pelabelan Islamisasi, tapi aktivitas yang sudah mereka lakukan semisal dengan makna Islamisasi. ${ }^{3}$ Gencarnya wacana Islamisasi ilmu pengetahuan ternyata tidak semudah yang dibayangkan, faktanya terjadi pro dan kontra dalam kubu internal ilmuwan muslim. Kritik yang dilontarkan pihak kontra cenderung mengarah kepada aspek metodologi dalam merealisasikan Islamisasi itu sendiri, karena langkah-langkah yang digagas oleh beberapa ilmuwan di nilai kurang ampuh untuk mewujudkan Islamisasi ilmu pengetahuan, bahkan sebagian menganggap itu langkah yang siasia. Sementara pihak pro menilai adanya perbedaan mencolok antara epistimologi Islam dan Barat dalam memproduksi ilmu pengetahuan, sehingga Islamisasi ilmu pengetahuan harus dilakukan untuk menangkal dampak dari pemikiran Barat tersebut.

Ajaran Islam tidak pernah melakukan dikhotomi antar ilmu satu dengan yang lain. Karena dalam al-Qur'an, kata ilm,atau pengetahuan digunakan baik untuk ilmu kealaman maupun jenis ilmu yang lain. Kajian tentang alam direkomendasikan dengan tujuan untuk menemukan pola-pola Tuhan di alam semesta dan memanfaatkanya demi kemaslahatan umat manusia. Karena sebenarnya ilmu agama dan umum merupakan anugerah yang berasal dari Allah. Sebagaimana firman-Nya dalam QS An-Naml 27:15, sebagai berikut :

\footnotetext{
${ }^{1}$ Juhaya S Praja, Filsafat dan Metodologi Ilmu Dalam Islam, Bandung, Teraju, 2002 , h. 77

${ }^{2}$ Juhaya S Praja, Filsafat dan Metodologi Ilmu Dalam Islam, 2002, h.76

${ }^{3}$ Hashim, Rosnani, Gagasan Islamisasi kontemporer Sejarah, Perkembangan dan Arah Tujuan, Islamia : Majalah Pemikiran dan Peradaban Islam, INSIST: Jakarta, Thn II No. 6/ Juli- September, 2006, h.46
} 


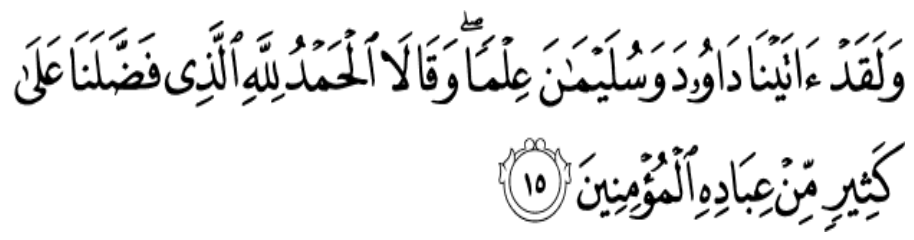

Dan sesungguhnya Kami telah memberi ilmu kepada Daud dan Sulaiman; dan keduanya mengucapkan: "Segala puji bagi Allah yang melebihkan kami dari kebanyakan hamba-hambanya yang beriman".

Islam juga menganjurkan kepada seluruh umatnya untuk bersungguhsungguh dalam mempelajari setiap ilmu pengetahuan. Hal ini dikarenakan alQur'an merupakan sumber dan rujukan utama ajaranNya memuat semua inti ilmu pengetahuan, baik yang menyangkut ilmu umum maupun ilmu agama. Memahami setiap misi ilmu pengetahuan pada dasarnya adalah memahami prinsip-prinsip al-Qur'an. Dalam menghadapi perkembangan budaya manusia dengan perkembangan iptek yang sangat pesat, dirasakan perlunya mencari keterkaitan antara system nilai dan norma-norma Islam dengan perkembangan tersebut.

\section{Sejarah Islamisasi Ilmu Pengetahuan}

Ide Islamisasi ilmu pengetahuan berangkat dari kondisi yang memprihatinkan di dunia Islam pada masa modern yang mengalami ketertinggalan ilmu pengetahuan dan dominasi ilmu pengetahuan sekuler yang dewasa ini berkembang di dunia Islam. Tokoh gerakan pemikiran Islamisasi ilmu pengetahuan yang terkenal adalah Ismail Raji al-Faruqi. Riwayat hidup AlFaruqi tidak bias dilepaskan dari konteks perkembangan sosio politik dan sejarah panjang bangsa dan Negara palestina sebagai tempat kelahirannya. Sebab di daerah tersebut hampr separuh usaia Al- Faruqi di habiskan di Palestina, sebelum akhirnya hijrah ke Amerika.

Al-Faruqi secara bersemangat mensinyalir bahwa penyebab tertinggalnya dunia Islam dibanding dunia barat modern, disebabkan kondisi pendidikan Islam yang mengalami krisis identitas, akibat pengaruh filsafat dan ilmu pengetahuan yang melanda system pendidikan Islam, yang berimplikasi pada terbelahnya sistem pendidikan Islam secara dikhotomik. Ismail Raji AlFaruqi dengan demikian bisa disebut sebagai cendekiawan muslim yang konsens dengan masalah epistimologi pendidikan Islam karena pemikirannya tentang islamisasi ilmu pengetahuan mejadi pemicu kesadaran sebagian pemikir muslim modern untuk melakukan upaya redefinisi dan reislamisasi terhadap ilmu pengetahuan yang berkembang pada masa modern dengan konsep-konsep ideal ilmu pengetahuan dalam bingkai filsafat Islam.

Pemikiran Islamisasi ilmu pengetahuan Al-Faruqi secara konkrit dan aplikatif berusaha mewujudkan dalam bentuk gerakan sistematik berupa pembuatan buku-buku ilmiah yang telah diislamkan terlebih dahulu, sebelum 
dijadikan referensi utama bagi proses pembelajaran pada jenjang pendidikan tinggi dalam Islam, oleh karena itu tampaknya Al-Faruqi berusaha mengembangkan kembali metodologi pengembangan ilmu pengetahuan berbasis ajaran Islam pada masa modern, sebagaimana keberhasilan ulama-ulama klasik dalam mengislamkan ilmu-ilmu yng berasal dari Yunani.

Al-Faruqi sendiri dalam risalahnya yang berjudul Islamization of Knowledge, banyak menampilkan kritiknya terhadap kondisi system pendidikan Islam pada masanya. Tidak dapat dipungkiri bahwa implikasi pemikirannya tentang Islamisasi telah banyak mempengaruhi paradigma pemikir muslim lainnya. Seperti munculnya beberapa lembaga studi Islam bahkan Al-Faruqi sendiri mendirikan sebuah lembaga studi yang sangat terkenal yaitu The International Intitute of Islamic Thought yang terkenal dengan singkatan III-T yang bermarkas di Virginia Amerika Serikat. Lembaga ini tersebar hingga beberapa Negara dikawasan Asia seperti Malaysia, Pakistan dan beberapa Negara Eropa, namun belakangan aktivitas organisasi pengkajian Islam tersebut mulai redup, diakibatkan krisis financial. Sebagai ilustrasinya adalah III T yang berada di Malaysia, institute ini sempat Berjaya hingga tahun 1998 dan menjalin kerjasama dengan IIUM ( international Islamic University of Malaysia). Namun sekarang pusat kajian itu kurang terdengar lagi gaungnya, dibandingkan misalnya dengan lembaga kajian sejenis yang didirikan oleh Syed Naquib alAttas yaitu ISTAC (Iternational Institute of Ilsmic Thougth and Civilization) yang berkedudukan di Kuala Lumpur. ${ }^{4}$

Di Indonesia juga terdapat pengaruh pemikiran Islamisasi ilmu pengetahuan yang digagas Al-Faruqi. Terutama mempengaruhi beberapa tokoh pembaharu Islam kontemporer Indonesia ada kemungkinan bahwa kecenderungan berupa semangat pengintegrasian ilmu yang terjadi belakangan ini dibeberapa perguruan tinggi Islam adalah efek secara langsung ataupun tidak langsung dari Islamisasi ilmu pengetahuan Al-Faruqi pada tahun 1970-an sampai tahun 1980-an dan pengaruh beberapa pemikir muslim lainnya yang satu ide dengan Al-Faruqi. Meskipun ide Islamisasi ilmu pengetahuan muncul dan dihubungkan dengan kedua tokoh di atas, tapi secara subtantif ide tersebut telah muncul abad ke-19, yaitu ketika Syah Waliyallah dan Sir Sayyid Ahmad Khan yang mendirikan universitas Aligarth. Kedua tokoh ini mempelopori kebangkitan pemikiran dan pengetahuan yang berorientasi kepada Islam dan sekaligus bercorak modern.

Dalam gerakan pemikirannya mereka menolak untuk kembali kepada tradisi lama dan juga menentang penetrasi dan dominasi barat dan menghegemoni masyarakat muslim. Kebangkitan pemikiran yang dipelopori oleh Ahmad Khan diilhami oleh kekalahan umat Islam India dalam menentang kekuasaan kolonial Inggris pada tahun 1857-1858, yang menimbulkan sikap antipati dan isolasi umat Islam. Dalam pandangannya, sikap ini tidaklah memberi

${ }^{4}$ M. Dawam Rahardjo, Strategi Islamisasi Ilmu Pengetahuan”, dalam Gagasan dan Perdebatan Islamisasi Ilmu Pengetahuan, Moeflih Hasbullahed. Jakarta:Pustaka Cidesindo,2000, h. 12-13 
manfaat bagi umat Islam. Untuk itu ia berinisiatif untuk mengadakan pembaharuan pemikiran dengan berpikiran ilmiah untuk menghadapi dominasi barat. Gerakan pemikiran di atas dilanjutkan oleh Muhammad Abduh dan Rasyid Ridlo dari Mesir. Mereka secara tegas menolak kembali kepada tradisi-tradisi pada masa lalu yang dibarengi kesediaan mereka untuk mengadopsi ilmu pengetahuan Barat.

Menurut Azyumardi Azra, Pada awalnya pandangan-pandangan keagamaan yang menjadi visi pemikiran Al-Faruqi terletak pada dua hal yaitu Arabisme dan Islam. Dalam studinya tentang Arab, ia menyusun sebuah tulisan terdiri dari 4 jilid yaitu : "on Arabism: Urubah and Religion" pada perjalanan berikutnya ia lebih memfokuskan kepada studi tentang Islam melalui diskursus ilmiah dan akademis serta gerakan advokasi politik dalam melihat pentingnya Islam.

Pada tahun 1960-an dan awal tahun 1970-an lebih gencar mempresentasikan Islam sebagai agama nalar dan ilmiah, maju dan par execellent. Ia menjadi seorang aktivis Islam yang menempatkan Islam sebagai acuan utama, yaitu sebagai ideologi yang lengkap dan menyeluruh. Dalam pandangan Al-Faruqi, salah satu kesalahan fatal umat Islam adalah menganggap ilmu itu terbelah dua, yaitu ilmu-ilmu sekuler (profane) dan ilmu-ilmu agama Islam. Ide Islamisasi ilmu pengetahuan yang dicetuskan Al-Faruqi dituangkan dalam risalah berjudul The Islamization of Knowledge yang diterbitkan oleh IIIT. Ide tersebut menjadi terkenal ketika seminar pertama mengenai Islamisasi Ilmu pengetahuan dilaksanakan di Islamabad, Pakistan pada Januari 1982.

Al-Faruqi berusaha mengingatkan dunia Islam akan suatu konflik antara ilmu pengetahuan dalam pandangan Barat dan Islam, yaitu dengan merencanakan suatu yang dapat menghindari terjadinya konflik tersebut, serta menggalakkan kembali pendidikan Islam sebagaimana yang diharapkan. Tokoh lain yang menggagas Islamisasi Ilmu adalah Syed Muhammad Naquib al-Attas. Ia lahir tanggal 5 september 1931 di Bogor, Jawa Barat. Pendidikannya dijalani dari Sekolah Dasar Johor Malaysia, setelah itu pada masa pendudukan Jepang ia kembali ke Jawa dan meneruskan pendidikannya di Madrasah Al Urwat al Wustha, Sukabumi.

Kegiatan intelektual Al-Attas di mulai di universitas Malaya pada pertengahan 1960-an dan telah dapat membangkitkan kesadaran baru akan pentingnya peranan Islam dalam sejarah, nasionalisme dan kebudayaan melayu. Ia telah berhasil menumbuhkan kesadaran baru tentang peranan Islam kepada mahasiswa dan masyarakat umum. Disamping itu ia mengkritisi berbagai disiplin ilmu filsafat, kebudayaan dan politik yang telah terbaratkan. Ide-ide itu terlukiskan dalam karya-karyanya yang antara lain The origin of the Malaya Syair (1968), Prelimenary Statement on the Islamization of the malayIndonesian Archepelago (1969) dalam hal ini Al-Attas bukan berarti antipati terhadap pemikiran barat. Dalam pengembangan disiplin-disiplin keilmuan tidak 
hanya didasarkan kepada ajaran- ajaran Islam, tetapi harus di analisis dengan filsafat Yunani dan Yahudi-kristen serta tradisi-tradisi klasik abad pertengahan.

\section{Konsep Dasar Islamisasi Ilmu Pengetahuan}

Dalam buku Webster New World College Dictionary, mendefinisikan kata "Islamisasi", sebagai to bring within Islam. ${ }^{5}$ Sedangkan makna yang luas adalah menunjuk pada proses mengislamkan, dalam konteks yang umum yakni berupa manusia, bukan saja ilmu pengetahuan atau obyek lainnya. ${ }^{6}$ Istilah Islamisasi juga berarti memberi muatan Islam pada sesuatu. ${ }^{7}$ Sedangkan menurut terminologinya Islamisasi adalah memberi dasar-dasar dan tujuan Islam yang diturunkan oleh Islam. ${ }^{8}$ Menurut Al-Attas Islamisasi merupakan pembebasan manusia dari segenap tradisi yang bersifat magis, sekuler yang membelenggu pikiran dan perilakunya. ${ }^{9}$ Sedangkan pengertian ilmu dan pengetahuan itu sendiri di kalangan para ahli masih terdapat berbagai pendapat yang berbeda-beda dalam mendefinisikan

Al-Faruqi mendefinisikan Islamisasi Ilmu Pengetahuan berarti upaya integrasi wawasan pengetahuan yang harus ditempuh sebagai awal proses integrasi kehidupan kaum muslimin. Pengintegrasian baru tesebut selanjutnya dimasukan dimasukkan ke dalam keutuhan warisan Islam dengan melakukan eliminasi, reinterpretasi dan adaptasi terhadap komponen-komponenya sebagai sebuah world view of Islam ( pandangan hidup Islam) dan menetapkan nilainilainya, serta adanya relevansi yang eksak antara Islam dengan filsafat, dan metode dan obyek-obyeknya. ${ }^{10}$

Ada beberapa alasan utama yang menjadi latar belakang program Islamisasi ilmu pengetahuan menurut Al-Faruqi yaitu kondisi realitas dunia Islam pada saat gagasan Islamisasi ilmu pengetahuan di di kemukakan. Menurut Al-Faruqi ada beberapa permasalahan serius yang sedang dihadapi umat Islam yang di sebutnya sebagai sebuah malaise (krisis) global yang di alami sebagian umat Islam di dunia.

Krisis tersebut telah menyebabkan umat Islam menempati posisi terendah diantara bangsa-bangsa lain, mereka mengalami pemerasan, penjajahan dan dirampas negerinya, dibantai serta dipaksa untuk meninggalkan agamanya. Sementara dalam kehidupan politik umat Islam terjadi perpecahan dan pertikaian yang memang sengaja diciptakan oleh Negara-negara Barat untuk lebih menciptakan ketidakstabilan, perpecahan antara umat Islam. Kondisi ini

\footnotetext{
${ }^{5}$ Webster New World College Dictionary, h.715. dalam Aziz M.Amin, Islamisasi sebagai Isu, Jurnal ulumul Qur'an, volume II, No.4, Tahun 1992, Jakarta: Ulumul Qur'an, 1992, h. 3

${ }^{6}$ Aziz M. Amin, Islamisasi sebagai Isu, h.3

${ }^{7}$ Dawam Rahardjo, Islam Menatap Masa Depan, Jakarta:P3M, 1989, h.10

${ }^{8}$ Dawam Rahardjo, Islam Menatap Masa Depan, h. 11

${ }^{9}$ Amin Rais, Cakrawala Islam: Antara Cita dan Fakta, Bandung: Mizan, 1991, h.86

${ }^{10}$ Ismail Raji Al-Faruqi, Islamization of Knowledge General Principles and Work Plann, Terj. bahasa Indonesia Islamisasi Pengetahuan, Terj. Anas Mahyuddin, Bandung: Pustaka,1984, h. 35
} 
disebabkan oleh usaha kaum kolonial dan menghancurkan seluruh institusi politik di Negara-negara Islam. ${ }^{11}$

Efek terburuk dari malaise yang dialami umat Islam telah mengakibatkan krisis serius yang dialami oleh berbagai Negara-negara muslim dalam berbagai bidang. kekalahan di bidang politik berimbas pada kekalahan dan keterbelakangan di bidang ekonomi. Kehidupan ekonomi umat Islam mengalami kehancuran dengan banyaknya kelaparan dan ketidakberdayaan ekonomi umat. Keadan ini menimbulkan ketergantungan yang luar biasa kaum muslim kepada pihak-pihak asing. Industri-industri yang diselenggarakan di Negara- Negara muslim tidak ditujukan untuk memenuhi kebutuhan umat Islam, tapi untuk kepentingan kaum kolonial.

Dalam bidang kegamaan dan budaya, umat Islam semakin tersesat dengan propaganda asing yang mengarah kepada westernisasi, tanpa disadari bahwa itu akan membawa kepada kehancuran budaya bangsanya dan ajaran Islam. Berbarengan dengan itu dibangunlah berbagai sekolah-sekolah yang menggunakan sistem dan kurikulum barat, yang selanjutnya melahirkan kesenjangan di antara umat Islam, yaitu mereka yang terlalu terbaratkan dan sekuler dan mereka yang tetap menentang sekulerisme. Pemerintah kolonial selalu berusaha agar golongan umat Islam yang pertama unggul dan menjadi penentu dalam pengambilan kebijakan umat Islam. ${ }^{12}$

Sebagai jawaban atas persoalan-persoalan umat Islam sebagaimana di atas, penting adanya langkah-langkah perbaikan. Al-Faruqi merkomendasikan pentingnya pemaduan pendidikan yang bersifat sekuler/ profane dengan pendidikan Islam. Dualisme pedidikan yang terjadi di kalangan umat Islam pada saat ini harus ditiadakan setuntasnya. Kedua sistem pendidikan tersebut harus dipadukan dan diintegrasikan, sehingga dapat melengkapi dan menutupi kekurangan masing-masing. Integrasi pendidikan sekuler dan pendidikan Islam

${ }^{11}$ Kekalahan-kekalahan umat Islam dimulai dengan ekspansi dan penetrasi Negara-negara Eropa ke wilayah-wilayah umat Islam pada abad ke delapan belas. Pada saat itu kekuatan Eropa mulai bangkit dan menembus kekuatan-kekuatan rezim-rezim umat Islam kekuatan-kekuatan Negara Atlantik dan Eropa telah menampakkan ambisi untuk menguasai dan memperluas wilayah kekuasaan mereka diwilayah perbatasan bagian utara dan selatan masyarakat Muslim. Eropa Barat dan Rusia pada abad ini telah memulai ekspansinya melalui Asia Tengah dan Siberia menuju Pasifik. Pada wilayah-wilayah masyarakat muslim di Selatan, ekspansi bangsa Eropa di mulai dengan perlawatan perdagangan para saudagar Portugis, Belanda dan Inggris. Portugis Mendirikan beberapa pusat kekuasaan colonial di Hindia dan Malaka. Pada abad 16 yang kemudian dilanjutkan Belanda yang menguasai Asia Tenggara pada abad ke 17. Sedangkan inggris melalui ekspansi mereka dengan menguasai sebuah imperium di India dengan melalui ersaingan yang ketat dengan Prancis. Pada abad akhir abad ke 18 Inggris telah berhasil menaklukan Bengal dan terus menjajah wilayah India. Lihat Ira M Lapidus, Sejarah Sosial Umat Islam, terj. Gufron A.Mas'adi, Vol. 1, Jakarta: Radja Grafindo Persada, 2000, h. 89

${ }^{12}$ Ismail Raji al-Faruqi, Islamisasi Pengetahuan,terj. Anas Mahyuddin, Bandung:Pustaka Setia, 1984, h.2-8 gambaran tentang munculnya pertentangan antara umat Islamnyang telah terbaratkan dengan mereka yang masih kokoh memegng ajaran Islam terjadi di Negara Turki dengan terbaginya umat Islam dalam pembaharuan di Turki, yaitu kaum sekuler, kaum nasionalis dan kaum agamawan ( Islam ). Golongan barat mengehendaki agar pembaharuan di Turki didasarkan pada pembaharuan Barat, golongan Islam mengehendaki pembaharuan tetap didasarkan kepada ajaran-ajaran Islam dan golongan nasionalis menghendaki pembaharuan di dasari pada nilai-nilai nasionalisme bangsa Turki. Lihat Harun Nasution, Pembaharuan dalam Islam, Sejarah Pemikiran dan Gerakan, Jakarta:Bulan Bintang,1985, h. 126 
harus menghasilkan sebuah sistem pendidikan yang sesuai dengan visi agama Islam.

Dari berbagai problematika umat Islam tersebut, tampaknya al-Faruqi berusaha meyakinkan bahwa proses Islamisi ilmu pengetahuan yang di kembangkannya diharapkan bisa menjadi barometer kebangkitan umat Islam dari kemunduran yang dihadapi sebagian besar kaum muslimin dalam berbagai bidang kehidupan yakni bidang politik, ekonomi dan religio budaya. Selanjutnya Al-Faruqi menjelaskan tentang langkah-langkah upaya Islamisasi ilmu pengetahuan, yaitu sebagai berikut:

1. Penguasaan disiplin ilmu modern, pengetahuan kategoris.

2. Survei disiplin

3. Penguasaan khazanah ilmiah Islam

4. Penguasaan khazanah Islam: tahap analisa

5. Penentuan relevansi Islam yang khas terhadap disiplin ilmu.

6. Penilaian kritis terhadap disiplin ilmu modern; tingkat perkembangan masa kini.

7. Penilaian kritis terhadp khazanah Islam; tingkat perkembangan dewasa ini

8. Survey permasalahan yang dihadapi oleh umat Islam

9. Survey permasalahan yang dihadapi oleh umat manusia

10. Analisa kreatif dan sintesis.

11. Penuangan kembali disiplin ilmu modern ke dalam kerangka Islam dalam bentuk buku daras (buku teks) tingkat universitas.

12. Adalah berbagai langkah terakhir kerja islamisasi ilmu pengetahuan yaitu penyebaran ilmu yang telah di islamisasi. ${ }^{13}$

Selain Al-Faruqi, tokoh yang mengemukakan pentingnya Islamisasi pengetahuan adalah Syed Naquib al-Attas . Al-attas memberikan pengertian Islamisasi pengetahuan sebagai pembebasan manusia dari magic, mitos, animism dan tradisi kebudayaan kebangsaan dan selanjutnya dominannya sekulerisme atas pikiran dan bahasanya. ${ }^{14}$

Al-Attas memandang bahwa umat Islam menghadapi tatangan terbesar saat ini yaitu dengan berkembangnya ilmu pengetahuan yang telah salah dalam memahami ilmu dan keluar dari maksud dan tujuan ilmu itu sendiri. Meskipun ilmu pengetahuan yang dikembangkan oleh peradaban barat telah memberikan manfaat dan kemakmuran kepada manusia, namun ilmu pengetahuan itu juga telah menimbulkan kerusakan dan kehancuran di muka bumi.

Ilmu pengetahuan yang dikembangkan di atas pandangan hidup, budaya dan peradaban barat, menurut Al-Attas dipengaruhi oleh lima faktor, yaitu : 1) mengendalikan akal, 2)bersikap dualistic, 3)menegaskan aspek eksistensi yang memproyeksikan kehidupan sekuler, 4)membela doktrin humanisme, dan 5)

${ }^{13}$ Ismail Raji Al-Faruqi, Islamization of Knowledge General Principles and Work Plann, Terj. bahasa Indonesia, Islamisasi Pengetahuan, Terj. Anas Mahyuddin, Islamisasi Pengetahuan, h.98-118. Lihat juga Mona Abu Fadl, Where East Meets West; The West on Agenda of Islamic Revival, Herndon, Virginia: international Institute of Islamic Thought, 1990, h. 54

${ }^{14}$ Ismail Raji Al-Faruqi,, Islamisasi Pengetahuan, h.98 
menjadikan drama dan sebagai unsur-unsur yang dominan dalam fitrah dan eksistensi manusia.

Islam memandang bahwa visi mengenai realitas dan kebenaran bukan semata-mata berkaitan dengan alam fisik dan keterlibatan manusia dalam sejarah, sosial, politik dan budaya sebagaimana dalam pandangan sekuler Barat terhadap dunia yang dapat dilihat. Realitas dan kebenaran dimaknai berdasarkan kajian secara metafisis terhadap dunia yang tampak maupun yang tidak Nampak. Dengan demikian Islam memandang realitas bagai sesuatu yang kelihatan dan gaib dunia akhirat. Dalam hal ini dunia tidak dapat dilepaskan dengan akhirat dan akhirat juga dapat dikesampingkan untuk kepentingan duniawi.

Dengan kekurangan-kekurangan ilmu pengetahuan di atas, Al-Attas meyakini pentingnya digagas suatu gerakan Islamisasi pengetahuan, karena ilmu pengetahuan modern tidak netral dan masuk budaya dan filosofis yang sebenarnya berasal dari refleksi kesadaran dan pengalaman manusia Barat. Islamisasi ilmu pengetahuan modern bukan memberikan label Islam pada ilmu penegetahuan dan menolak semua yang berasal dari Barat, karena terdapat beberapa persamaan antara Islam dengan filsafat Barat.

Islamisasi ilmu pengetahuan menurut Al-Attas dapat dilakukan dengan melalui dua proses yang berkaitan yaitu :

1. Mengisolir unsur-unsur dan konsep-konsep kunci yang membentuk peradaban Barat yang dimiliki oleh pengetahuan modern saat ini terutama ilmu pengetahuan humaniora. Dengan demikian ilmu-ilmu alam, fisika dan aplikasinya harus ditundukkan dengan ajaran-ajaran Islam, khususnya dalam fakta-fakta dan formulasi teori-teori lainnya. Fakta dianggap tidak benar jika itu bertentangan dengan pandangan hidup Islam.Unsur-unsur dan konsep-konsep asing yang merusak ajaran Islam tersebut adalah: konsep dualisme yang meliputi hakikat dan kebenaran, doktrin humanisme, ideology sekuler, konsep tragedi khususnya dalam kesusastraan. Keempat unsur asing tersebut telah menjangkiti ilmu khususnya dalam bidang sains kemanusiaan dan kemasyarakatan, sains fisik, terapan yang melibatkan perumusan fakta dan teori. Konsep-konsep inilah yang membentuk pemikiran dan peradaban Barat dan telah menular dikalangan umat Islam.

2. Memasukan unsur-unsur, konsep-konsep Islam dalam setiap bidang dari ilmu pengetahuan modern yang relevan.

Konsep-konsep Islam yang harus menggantikan konsep-konsep Barat tersebut adalah: manusia, din, 'ilm dan ma'rifah, hikmah, al- 'adl, amal-adab dan konsep kulliyat-jamiyah (universitas). Jika kedua proses Islamisasi tersebut dilakukan, maka manusia akan terbebas dari magic, mitologi, animisme, dan tradisi budaya yang bertentangan dengan Islam. Islamisasi ilmu pengetahuan akan membebaskan manusia dari keraguan (syakk), dugaan (dzann) dan argumentasi kosong menuju keyakinan akan kebenaran mengenai realitas spiritual dan materi. Islamisasi akan membebaskan ilmu 
pengetahuan modern dan ideologi, makna dan pernyataan-pernyataan sekuler. ${ }^{15}$

Al-Attas menolak bahwa Islamisasi ilmu pengetahuan sekedar memberikan labelisasi ilmu dengan prinsip-prinsip Islam. Islamisasi ilmu pengetahuan bertujuan agar umat Islam terlindungi dari pengaruh ilmu pengetahuan yang telah terjangkit unsur-unsur dan konsep Barat yang akan menimbulkan kesesatan dan kekeliruan, serta bertujuan mengembangkan ilmu yang hakiki yang dapat membngunkan pemikiran dan kepribadian umat Islam dan dapat menaambahkan keimanan kepada Allah SWT. Dengan demikian Islamisasi ilmu pengetahuan akan melahirkan keamanan, kebaikan, keadilan, keselamatan dan keimanan kepada Allah SWT.

\section{Implikasi Ilmu Pengetahuan dalam Pendidikan}

\section{Aspek Kelembagaan}

Islamisasi dalam aspek kelembagaan ini dimaksud adalah penyatuan dua sistem pendidikan, yakni pendidikan Islam (agama) dan sekuler (umum). Artinya melakukan modernisasi bagi lembaga pendidikan agama dan Islamisasi pendidikan sekuler. Adanya lembaga pendidikan modern (Barat sekuler), dipandang sebagai kamuflase yang mengatas namakan Islam dan menjadikan Islam sebagai simbol, untuk mengantisipasi keadaan ini maka perlunya dibangun lembaga pendidikan baru sebagai tandingan.Sepertinya implikasi dari Islamisasi ilmu pengetahuan pada aspek kelembagaan adalah terbentuknya lembaga independen yang mengintegrasikan pengembangan keilmuan agama dan umum, jadi apapun nama lembaganya tersebut yang terpenting adalah terintegrasinya secara komprehensif antara sistem umum dan agama. Meskipun dalam tatanan sistematika keorgaanisasian lembaga mengadopsi barat namun secara subtansial menerapkan sistem Islam.

2. Aspek Kurikulum

Mengkaji kurikulum tidak diserahkan pada satu tim saja, namun membutuhkan ahli-ahli dibidangnya, perbincangan ini harus dimulai sejak awal Islamisasi. Dalam hal ini kurikulum yang telah dikembangkan di Barat tidak boleh diabaikan. Rumusan kurikulum dalam Islamisasi ilmu pengetahuan dengan memasukkan segala keilmuan dalam kurikulum. Dengan demikian lembaga pendidikan memiliki kurikulum yang actual, responsive

15 Menurut Al-Attas, istilah sekuler berasal dari kata seacullum yang mempunyai pengertian waktu ( time ) dan tempat ( location ). Dengan demikian seacullum itu berarti masa kini dan di sini. Masa kini berarti masa sekarang dan di sini berarti dunia ini. Jadi paham sekuler menurut Al-Attas adalah merujuk pada makna kesaatinian dan kedi simian. Kalau kata sekuler itu diterjemahkan ke dalam bahasa Arab, maka kata yang paling mendekati kesesuaian adalah kedisinian ( hunalaniyah ), berdasarkan perkataan dalam bahasa Arab huna yang berarti di sini dan al 'an yang berarti sekarang. Berdasarkan analisis di atas, Al-attas menerjemahkan sekuler ke dalam Bahasa Arab dengan almaniyah sebenarny tidak menjelaskan pengertian konsep aliran itu. Dalam kesempatan lain Al-Attas menyarankan agar sekulrisme diterjemahkan dengan syikulariyah dalam bahasa Arab, sehingg dapat memberikan pemahaman yang benar di kalangan umat Islam dengan tidak mereduksi makna dari konsep itu. Lihat Ugi Suharto, Islam dan Sekularisme, Islamia, Tahun I, No.6, Juli-September, 2006. 
terhadap tuntutan permasalahan kontemporer. Artinya lembaga akan melahirkan lulusan yang visioner, berpandangan integrative, proaktif dan tanggap terhadap masa depan serta tidak dikotomik dalam keilmuan.

3. Aspek Pendidik

Dalam hal ini pendidik ditempatkan pada posisi yang selayaknya, artinya kompetensi dan professional yang mereka miliki dihargai sebagaimana mestinya. Bagi Al-Faruqi tidak selayaknya para pendidik mengajar degan prinsip keikhlasan, pendidik diberikan honorarium sesuai dengan keahliannya.Terkait dengan pengajar yang memberikan pembelajaran pada tingkat dasar dan lanjutan tidak dibenarkan Islamologi atau misionaris, artinya harus pendidik yang benar-benar Islam dan memiliki basic keislaman yang mantap. Di samping itu, staf pengajar yang diinginkan dalam universitas Islam adalah staf pengajar yang saleh serta memiliki visi keislaman.

Dengan demikian harus ada rumusan yang jelas tentang kriteria calon pendidik, selain indeks prestasi (IP) sebagai parameter kualitas intelektual, penting dilakukan wawancara menyangkut aqidah, keimanan, keaagamaan, jiwa dan sikap terhadap jabatan, kriteria ini juga harus ditopang oleh kode etik Islam tentang profesi pendidik. Seorang pendidik dituntut mempunyai kemampuan subtantif, yakni berupa gagasan dua segi keilmuan, yakni ilmu agama dan ilmu modern sekaligus.

Selain kemampuan subtantif seorang pendidik juga dituntut memiliki kemampuan nonsubtantif, yakni berupa multiskill didaktis. Kemampuan ini mencakup ketrampilan dalam menggunakan metode dan strategi pembelajaran, pengelolaan atau manajemen pendidikan, pengevaluasian dan lain sebagainya, yang secara keseluruhan bertumpu pada unsur tauhid.

\section{Islamisasi Ilmu Pengetahuan dan Pendidikan Islam}

Pandangan Al-Faruqi dan Al-Attas tentang islamisasi ilmu pengetahuan, dalam kerangka operasionalnya islamisasi ilmu pengetahuan menurut Muhaimin terdiri dari beberapa model yaitu:

1. Purifikasi, yaitu Islamisasi ilmu pengetahuan yang mempunyai arti penyucian dan pembersihan. Model ini mengandung pengertian Islamisasi ilmu pengetahuan harus dapat menyucikan ilmu pengetahuan agar sesuai dan sejalan dengan ajaran Islam. Model ini yang dikenal dalam pemikiran Al-Faruqi dan Al-Attas dalam Islamisasi ilmu pengetahuan. Al-Faruqi menggunakan model ini dengan memberikan langkah-langkah dalam Islamisasi, yaitu (a)menguasai khazanah intelektual Muslim, (b) menguasai khazanah ilmu pengetahuan modern, (c)identifikasi kekurangankekurangan ilmu pengetahuan modern dalam perspektif ajaran Islam, (d) rekonstruksi ilmu pengetahuan agar selaras dengan ajaran Islam.

2. Modernisasi, Islamisasi ilu pengetahuan model modernisasi adalah membangun semangat umat Islam untuk selalu modern, maju, progresif, terus menerus mengusahakan perbaikan-perbaikan bagi diri dan 
masyarakatnya agar terhindar dari keterbelakangan dan ketertinggalan dibidang ilmu pengetahuan. Sebagai seorang modernis seringkali berusaha memahami ajaran-ajaran dan nilai-nilai mendasar yang terdapat dalam AlQur'an dan Al-Hadits, dengan mempertimbangkan khazanah intelektual pada masa kontemporer dan mengabaikan pemikiran-pemikiran tokoh intelektual muslim klasik.

3. Neo modernisme, Islamisasi ilmu pengetahuan dengan pola neomodernisme adalah upaya memahami ajaran-ajaran Islam yang terkandung dalam Al-Qur'an dan Al-Hadits dengan memperhatikan pemikiran intelektual muslim klasik dengan menggunakan pendekatanpendekatan yang digunakan ilmu pengetahuan kontemporer. Model ini berlandaskan pada metodologi sebagai berikut: (a) persoalan-persoalan umat Islam kontemporer harus dicari penjelasannya dari hasil ijtihad pemikir Islam terdahulu yang merupakan hasil penafsiran terhadap alQur'an, (b) jika dalam tradisi dan ijtihad ulama terdahulu tidak ditemukan maka ditelaah kondisi sosio cultural sehingga lahir ijtihad ulama-ulama tersebut, (c) telaah sosio historis akan melahirkan etika social al-Qur'an, (d) etika sosial al-Qur'an menghasilkan penjelasan dalam menjawab persoalan umat Islam dengan bantuan pendekatan ilmu-ilmu modern.

Dalam konteks Pendidikan Islam, Islamisasi ilmu pengetahuan dengan model purifikasi dapat diterapkan misalnya dalam mempurifikasi teori pengetahuan modern dalam pendidikan, yang kemudian disesuaikan dengan pemikiran para tokoh intelektual muslim. Sebagai contoh, teori yang berkaitan dengan faktor-faktor yang mempengaruhi perkembangan seseorang kaitannya dengan belajar. Terdapat tiga aliran yang menerangkan faktor-faktor yang mempengaruhi perkembangan jiwa seseorang yaitu; (a) Aliran Nativisme, aliran ini meyakini bahwa perkembangan jiwa seseorang dipengaruhi oleh faktor pembawaan; (b) Aliran Empirisme, yang meyakini bahwa perkembangan jiwa seseorang dipengaruhi oleh lingkugan; dan (c) aliran konvergensi yang mendudukan kedua faktor di atas. ${ }^{16}$

Dalam khazanah pemikiran intelektual muslim klasik dikenal perkataan Al-Syafii yang terkenal yaitu " ilmu itu adalah cahaya Allah tidak diberikan pada orang-orang yang melakukan maksiyat kepada-Nya. Perkataan Al-Syafiidi atas menegaskan ada faktor hidayah yang mempengaruhi perkembangan seseorang, sedangkan Islamisasi ilmu pengetahuan dengan model modernisasi dalam konteks pendidikan, berkaitan dengan modernisasi pendidikan Islam baik secara kelembagaan dalam hal ini pesantren dan madrasah maupun dalam pengembangan kurikulum. Dalam modernisasi pendidikan pesantren dikenal dengan berbagai sistem dan metode pembelajaran yang dilaksanakan pesantren. Sejarah pembelajaran pesantren yang pada awal pertumbuhannya menggunakan

16 Muhibbin Syah, Psikologi Pendidikan Dengan Pendekatan Baru, Bandug: Remaja Rosda Karya, 2002, h. 43- 46 
sistem non kelas, diubah dan diperbaiki dengan sistem berkelas (klasikal) dan berjenjang mulai tingkat dasar (ibtida'iyah), menengah pertama ( Tsanawiyah), maupun menengah atas ('aliyah). Demikian juga dalam pendidikan madrasah selama ini telah diadakan perbaikan- perbaikan diantaranya dengan munculnya berbagai madrasah unggulan seperti MAPK, yang kini berubah menjadi MAK. Selanjutnya dalam pengembangan kurikulum, lembaga-lembaga pendidikan Islam terutama madrasah terjadi perubahan-perubahan kurikulum menuju kesempurnaan.

Selanjutnya Islamisasi pengetahuan dengan model neo modernisme dalam pendidikan Islam misalnya dapat dilakukan dengan mengangkat penyataan $\mathrm{Al}$ Ghazali yang memberikan anjuran-anjuran kepada guru dalam mengajar. AlGhazali menyatakan mengajar adalah pekerjaan dan tugas yang mulia.

Sedemikian tinggi penghargaan Al-Ghazali terhadap pekerjaan guru sehingga ia memberikan perumpamaan sebagai Matahari, yang merupakan sumber kehidupan dan sumber penerangan di langit dan di bumi. Perkataan AlGhazali di atas dapat dijadikan sebuah penekanan tentang bagaimana guru harus mengajar dan membimbing anak, yang ditekankan pada pencitraan figure guru yang dapat menjadi teladan bagi anak didiknya di samping sebagai pengajar dan pendidik. Ini untuk menjawab persoalan mendasar pendidikan umat Islam masa sekarang, ketika umat telah kehilangan figure-figur teladan yang patut dicontoh dan di tiru.

\section{SIMPULAN}

Dari penjelasan di atas dapat disimpulkan bahwa pada dasarnya Islamisasi ilmu pengetahuan merujuk pada usaha memurnikan dan melepaskan konstruksi ilmu pengetahuan dari pemikiran-pemikiran yang bertentangan dengan Islam. Islamisasi tidak hanya sekedar kegiatan ayatisasi dan pelabelan Islam terhadap suatu ilmu, namun lbih kepada proses membina dan membangun metodologi yang tepat berdasarkan konsep Islam, sehingga ilmu pengetahuan yang muncul akan mengikuti konstruksi yang telah digariskan oleh Islam yang berasal dari Tuhan yang maha Esa

Dalam kajian ilmu, Islamisasi ilmu pengetahuan menjadi penting dalam pendidikan dengan lebih menampilkan ajaran-ajaran Islam yang relevan dalam pengembangan pendidikan saat ini, mengingat semakin berkurangnya nilai-nilai Islam yang menjadi acuan dalam proses pendidikan bangsa ini. Pengertian Islamisasi ilmu pengetahuan ini secara jelas diterangkan oleh Al-Attas, yaitu: pembebasan manusia dari tradisi magis, mitologis, animistis, kultur nasional (yang bertentangan dengan Islam) dan dari belenggu paham sekuler dirinya terhadap pemikiran dan bahasa juga pembebasan dari control dorongan fisiknya yang cenderung sekuler dan tidak adil terhadap hakikat diri atau jiwanya, sebab manusia dalam wujud fisiknya cenderung lupa terhadap hakikat dirinya yang sebenarnya dan berbuat tidak adil terhadapnya. 
Gagasan Islamisasi ilmu pengetahuan muncul pada saat diselenggarakan sebuah konfrensi dunia yang pertama tentang pendidikan muslim di Mekkah pada tahun 1977. adapun salah satu gagasan yang direkomendasikan adalah menyangkut Islamisasi Pengetahuan. Gagasan ini antara lain dilontarkan oleh Muhammad Naquib Al-Attas dan Ismail Raji Al-Faruqi.

Islamisasi ilmu pegetahuan adalah pembebasan umat Muslim dari nilainilai ilmu pengetahuan yang bertentangan dengan pandangan hidup Islam. Dalam bahasa Al-Attas, Islamisasi Ilmu pengetahuan adalah Dewesternisasi ilmu pengetahuan ( Dewesternitation of knowledge)

Implikasi dari Islamisasi ilmu pengetahuan pada aspek kelembagaan adalah terbentuknya lembaga independent yang mengintegrasikan pengembangan keilmuan agama dan umum, rumusan kurikulum dalam Islamisasi ilmu demikian, lembaga memiliki kurikulum yang aktual, responsive terhadap tuntutan permasalahan kontemporer. Artinya lembaga akan melahirkan lulusan yang visioner, berpandangan integrative, proaktif dan tanggap terhadap masa depan serta tidak dikhotomis dalam keilmuan. Implikasi terhadap pendidik adalah pendidik ditempatkan pada posisi yang selayaknya, artinya kompetensi dan profesionalitas yang mereka miliki dihargai sebagaimana mestinya.

Pada akhirnya Islamisasi ilmu pengetahuan Al-faruqi juga berpengaruh pada pengembangan dasar-dasar filosofis pendidikan Islam. Hal ini dapat dilihat dari perhatian serius yang ditunjukan oleh Al-Faruqi dalam konstruksi pemikirannya dan konsens terhadap masalah pengembangan pendidikan Islam dan kritiknya terhadap pendidikan Islam. Al Faruqi juga secara aktif berusaha mensosialisasikan pokok-pokok pikirannya melalui konsep islamisasi ilmu pengetahuan tentang bagaimanan merekonstruksi konsep dasar pendidikan Islam yang ideal dengan menawarkan konsep-konsep metodologi pemikiran pendidikan Islam modern yang merupakan perpaduan sistem pendidikan Islam klasik dengan system pendidikan modern, kemudian menawarkan suatu metodologi alternative tentang studi yang berbasis tauhid dan peradaban Islam.

Penulis berkesimpulan bahwa gagasan Islamisasi ilmu pengetahuan yng dikemukakan Al-Faruqi adalah sebuah iktiar yang perlu mendapatkan respon positif. Meskipun gagasannya tak luput dari berbagai kelemahan, namun begitu sebagai sebuah wacana keilmuan modern, ide-ide pembaruan al-faruqi secara realitas telah diakui sebagai bagian integral dari trend pemikiran modernisme islam pada abad ke 20. Gagasan islamisasi ilmu pengetahuan secara metodologis juga bersinggungaan dengan masalah paradigm pendidikan Islam, kritik-kritik yang dilontarkan Al-Faruqi harus menjadi stimulus para pemerhati pendidikan akan pentingnya pengkajian metodologi keilmuan berbasis filsafat materialisme yang berasal dari Barat dan pentingnya memperteguh wawasan Islam yang lebih universal. Semangat dan perjuangan Al-Faruqi yang sangat kuat dalam mempertahankan identitas keislaman bagi generasi penerus Islam, seharusnya mendapat apresiasi yang baik. 


\section{DAFTAR PUSTAKA}

Amin Rais, Cakrawala Islam: Antara Cita dan Fakta, Bandung: Mizan, 1991

Aziz M.Amin, Islamisasi sebagai Isu, Jurnal ulumul Qur'an, volume II, No.4, Tahun 1992.

Harun Nasution, Pembaharuan dalam Islam, Sejarah Pemikiran dan Gerakan, Jakarta:Bulan Bintang, 1988

Hashim, Rosnani, Gagasan Islamisasi kontemporer Sejarah, Perkembangan dan Arah Tujuan, Islamia : Majalah Pemikiran dan Peradaban Islam, INSIST: Jakarta, Thn II No. 6/ Juli- September, 2006.

Ira M Lapidus, Sejarah Sosial Umat Islam, terj. Gufron A.Mas'adi, Vol. 1, Jakarta: Radja Grafindo Persada, 2000.

Ismail Raji Al-Faruqi, Islamization of Knowledge General Principles and Work Plann, Terj. bahasa Indonesia Islamisasi Pengetahuan, Terj. Anas Mahyuddin, Bandung: Pustaka,1984.

Juhaya S Praja, Filsafat dan Metodologi Ilmu Dalam Islam, Bandung, Teraju, 2002.

M. Dawam Rahardjo, Strategi Islamisasi Ilmu Pengetahuan”, dalam Gagasan dan Perdebatan Islamisasi Ilmu Pengetahuan, Moeflih Hasbullahed. (Jakarta: Pustaka Cidesindo, 2000.

M. Dawam Rahardjo, Islam Menatap Masa Depan, Jakarta:P3M, 1989.

Mona Abu Fadl, Where East Meets West; The West on Agenda of Islamic Revival, Herndon, Virginia: international Institute of Islamic Thought, 1990.

Muhibbin Syah, Psikologi Pendidikan Dengan Pendekatan Baru, Bandug: Remaja Rosda Karya, 2002.

Ugi Suharto, Islam dan Sekularisme, Islamia, Tahun I,No.6, Juli-September, 2006 